\title{
Evaluating change in agricultural landscape pattern between 1980 and 2000 in the Loess hilly region of Ansai County, China
}

\author{
Bo-Jie Fu ${ }^{\text {a,* }}$, Chen-Xia Hu ${ }^{\text {a }}$, Li-Ding Chen ${ }^{a}$, \\ Olivier Honnay ${ }^{\mathrm{b}}$, Hubert Gulinck ${ }^{\mathrm{b}}$ \\ ${ }^{a}$ Key Lab of Systems Ecology, Research Center for Eco-Environmental Sciences, Chinese Academy of Sciences, \\ P.O. Box 2871, Beijing 100085, PR China \\ ${ }^{\mathrm{b}}$ Department of Land Management, Katholieke Universiteit Leuven, Vital Decosterstraat 102, B-3000 Leuven, Belgium
}

Received 29 June 2005; received in revised form 28 October 2005; accepted 16 November 2005

Available online 18 January 2006

\begin{abstract}
Sustainability has become an important discussion topic across the world since the late 1980s. However, there is still lack of knowledge about the landscape sustainability and its quantitative evaluation, especially at local and regional scale levels. The sustainable development of the Chinese Loess Plateau has always been a focus in China mainly because of the occurring severe soil erosion. This study investigates the changes of the landscape pattern and the changes of the ecological sustainability of the agricultural landscapes in Ansai County between 1980 and 2000, which is located in the northern part of the Chinese Loess Plateau. Using a landscape typology as a spatial reference framework, the concept of hemeroby was used, in a multidisciplinary approach, for the assessment of the ecological aspect of agricultural landscape sustainability. We combined expert judgement with a regression model and a Geographic Information System. Fourteen variables describing the landscape structure were chosen as predictors for hemeroby. The research showed that the major changes in the agricultural landscape pattern were caused not only by socio-economic factors but also by the government policies over the past two decades, such as the large-scale eco-environment conservation programmes starting in the late of the 20th century. One of these programmes is known as the Grain-for-Green Programme (initiated in 1999). Between 1980 and 2000, the proportion of cropland-dominated landscape sharply decreased while the percentage of the mixed farmland-grassland landscape and the mixed farmland-woodland-grassland landscape increased. Meanwhile, the ecological sustainability of the agricultural landscape as a whole tended to become more sustainable, except a few landscape types. Among variables describing landscape pattern, patch size standard deviation (PSSD), total edge (TE), mean shape index (MSI), landscape shape index (LSI) and Shannon's evenness index (SEI) were shown to be the significant predicators for hemeroby. Although some data limitation, landscape structure turned out to be a good predicator for land use intensity and ecological sustainability of agricultural landscape estimated by hemeroby. As a highly integrative indicator, the concept of hemeroby provides a framework for the comparison of different land use pattern.
\end{abstract}

(C) 2005 Elsevier B.V. All rights reserved.

Keywords: Agricultural landscape; Hemeroby; Landscape structure; Ecological sustainability; The Loess Plateau; China

\section{Introduction}

Landscapes are the outcome of the interaction between socio-economic and natural forces (Wrbka et al., 2004).

\footnotetext{
* Corresponding author. Tel.: +8610 68597542; fax: +86 1062943840.

E-mail address: bfu@mail.rcees.ac.cn (B.-J. Fu).
}

During the evolution of cultural landscapes throughout the world, human activities have become a dominant factor shaping most agricultural landscapes (Goudie and Viles, 1997). As an interface between natural conditions and anthropogenic influence, and the most important socioeconomic driving forces of both global and local environmental change, change in land use and land cover is one of 
the main factors that man influences the environment, and it play a major role in the dynamics and changes of landscapes (Kim et al., 2002; Krausmann et al., 2003; Turner et al., 1990; Vitousek, 1992; Vitousek et al., 1997). The modification and conversion of land cover and land use are driven by the interaction in space and time between biophysical and human dimensions (Turner et al., 1993). However, human factors determine where and to what extent land use are modified at a certain location (Verburg and Chen, 2000).

Agricultural landscapes are mosaics of physical and human-managed patches that vary in size, shape and arrangement (Forman and Gordron, 1986). It is known that the landscape spatial pattern and the occurring ecological processes strongly interact. On the one hand, the shape and spatial distribution of the landscape elements may influence a variety of ecological processes (Forman, 1995; Forman and Gordron, 1986; Fu and Chen, 2000; Odum and Turner, 1989). Changes in ecological processes, on the other hand, may result in variation of landscape spatial pattern.

Human influence inclines to result in a simplification and geometrization of landscape structure (Forman and Gordron, 1986; Krummel et al., 1987; Odum and Turner, 1989; Rex and Malanson, 1990; Turner, 1990; Turner and Ruscher, 1988; Peterseil et al., 2004). Therefore, based on the hypothesis that there is a link between the intensity of land use and landscape structure (Moser et al., 2002; Odum and Turner, 1989), landscape structure has been used as a shortcut for determining the land use intensity and therefore as a predicator for ecological sustainability (Peterseil et al., 2004). Landscape structure has not only been used to evaluate the ecological value of landscapes, but also used to measure ecological aspect of the sustainability of land use pattern (Odum and Turner, 1989; Wrbka et al., 2004).

Hemeroby or hemerobic state is an integrated measure for the anthropogenic influence on landscapes or habitats. It was introduced in ecology by Jalas (1955), and it was later extended to plant communities and to the geosphere. According to Sukopp (1976) the hemeroby is "an integrative measure for the impacts of all human intervention on ecosystems, whether they are intended or not. The degree of hemeroby is the result of the impact on a particular area and the organisms which inhabit it." Hemeroby increases with the increase of the human influence. The degree of hemeroby is measured by indicators such as the share of neophytic and therophytic species, morphological and chemical soil features and land use types (Steinhardt et al., 1999). The application of the hemerobic state has been widely used by scientists in the field of landscape ecology or forestry in Central Europe (Zechmeister and Moster, 2001). Land use intensity and transformation of landscape patterns can also be characterized by the hemerobiotic state or hemeroby. Ecological sustainability was defined in the light of naturalness and biodiversity. As a measure for naturalness or conversely the human influence on ecosystem, hemeroby can be used for the assessment of ecological sustainability. The deviation of the hemerobiotic state of a certain landscape compared to the average situation of that landscape type was taken as a sustainability indicator in ecological terms. This approach was developed within the Spatial Indices for Land Use Sustainability (SINUS) project in Austria and was termed "Concept of Relative Deviance" (Peterseil et al., 2004). Hemeroby is therefore used in this study as a surrogate for land use intensity and a sustainability measure index for agricultural landscapes.

The Loess Plateau is situated in the middle reaches of the Yellow River. As one of the most serious soil and water loss areas in the world, over $60 \%$ of the land in the Loess Plateau in China has been suffering from soil erosion as a result of irrational land use and poor vegetation coverage, and this erosion has seriously depleted land resources and degraded the eco-environments (BREST-CAS, 1992; Fu, 1989; Fu and Gulinck, 1994; Shi and Shao, 2000). During the past decades, agriculture has been the primary economic activity and income source in the area, and the most important land use change induced by human was the clearing of forestland and grassland for agricultural purposes (Chen et al., 2001). Historical deforestation is considered to be the main cause of water and soil erosion in the basin of the Yellow River. Present records show the annual soil loss in these basins to be as high as 4 billion tonnes due to deforestation and cultivation of hillside agricultural lands (World Wildlife Fund, 2004).

Increasing attention was paid to soil erosion control and agricultural sustainable development in the Loess Plateau by the Chinese central government. To reduce soil erosion, improve the ecological and environmental status and promote the development of the rural area in western China, some sloping croplands have been converted to woodlands and grasslands in the past decades as a part of the government effort. The central government initiated a nationwide cropland set-aside programme known as Grainfor-Green Programme in 1999. The programme required those sloping arable lands with a slope of greater than $25^{\circ}$ be converted to woodland and pasture. The programme is believed to be one of the world's largest conservation projects (World Wildlife Fund, 2004). The Loess Plateau is also one of the target areas in the Grain-for-Green Programme. The project not only plays a vital role to maintain the ecological security, but also promote regional sustainable development.

Therefore, the assessment of ecological sustainability on agricultural landscape changes in Loess hilly area in China is essential for sustainable development of agriculture and sustainability of the Grain-for-Green Programme. The Ansai County of the northern Loess Plateau in China was chosen as the study area for analyzing the changes of agricultural 
landscape pattern and subsequently, of the ecological sustainability of agricultural landscape between 1980 and 2000.

This study aims to: (1) analyze the changes in the agricultural landscape pattern and identify the main driving factors in Ansai County; (2) assess, quantitatively and qualitatively, the ecological sustainability of the agricultural landscape change at the local scale.

\section{Materials and methods}

\subsection{Study area}

The study area, Ansai County, is situated between $36^{\circ} 31^{\prime}-37^{\circ} 20^{\prime} \mathrm{N}$ and $108^{\circ} 52^{\prime}-109^{\circ} 26^{\prime} \mathrm{E}$, and covers an area of $2951 \mathrm{~km}^{2}$ (Fig. 1). Ansai is a typical county characterized by semi-arid climate and hilly Loess landscape in the Loess

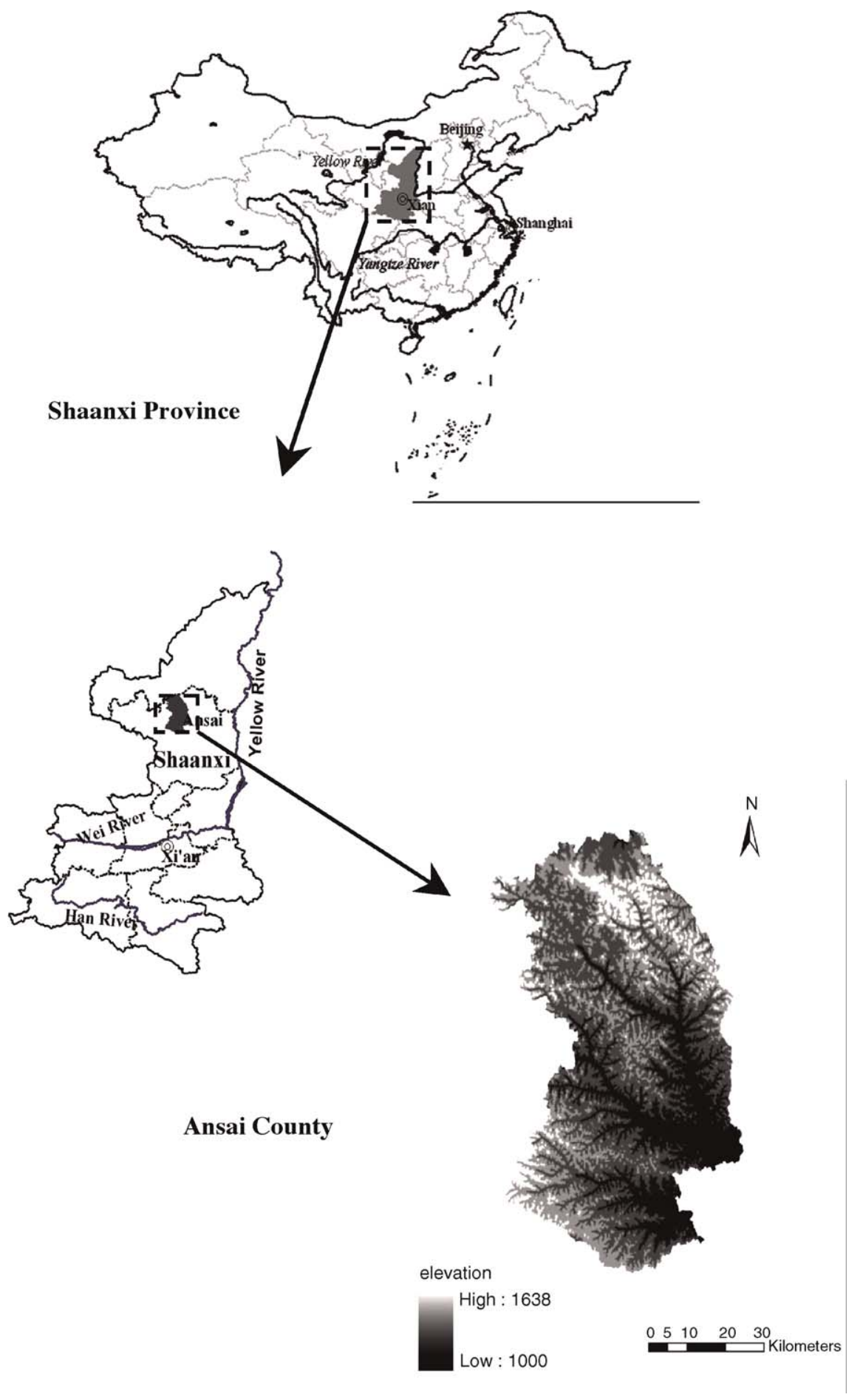

Fig. 1. The location of the study area. 
Plateau. The mean annual precipitation is about $520 \mathrm{~mm}$ and the mean annual temperature is $8.6^{\circ} \mathrm{C}$, both of which have clear seasonal variation. The land surfaces, mostly at an elevation between 1200 and $1500 \mathrm{~m}$, are highly dissected by deeply incised gullies with about $95 \%$ of the area being hilly land. Arable farming mostly occurs on the sloping lands without irrigation (Lu et al., 2004). Referring to the Soil Map of the World (FAO-Unesco, 1974), the soils in this part of the Loess Plateau, are classified as Calcic Cambisols.

Natural grassland with low coverage and sloping cropland are the two dominant landscape types in the area. By the end of 2000, there are about 1272 ha of sloping croplands that have been converted into woodland and pasture in Ansai County as a result of the Grain-for-Green Programme (Wang et al., 2003).

\subsection{Data used}

To assess the ecological sustainability of the agricultural landscape change and the impact of Grain-for-Green Programme on the sustainability of the agricultural landscape in Loess hilly area, we took advantage of the existing "Spatial Indices for Land Use Sustainability (SINUS)" approach (Peterseil et al., 2004). This approach was initiated by environmental researchers in Austria to develop reliable, operational, and spatially explicit indicators of practical use in long-term monitoring and assessment of ecological sustainability of Austrian cultural landscapes (Peterseil et al., 2004). Two land use maps (1980 and 2000, scale 1:100,000; Zhang, 2002), which were derived from Landsat TM remote sensing images, were collected and analyzed.

\subsection{Spatial referencing units}

As a referencing unit for statistical analysis, a grid mesh of $600 \mathrm{~m} \times 600 \mathrm{~m}$ size was used, according to a review of literature (Peterseil et al., 2004; Wrbka et al., 2004; Zechmeister and Moster, 2001) and taking into account the data type. The single grid cell that is the basic analysis unit is further referred to as the 'landscape cell'.

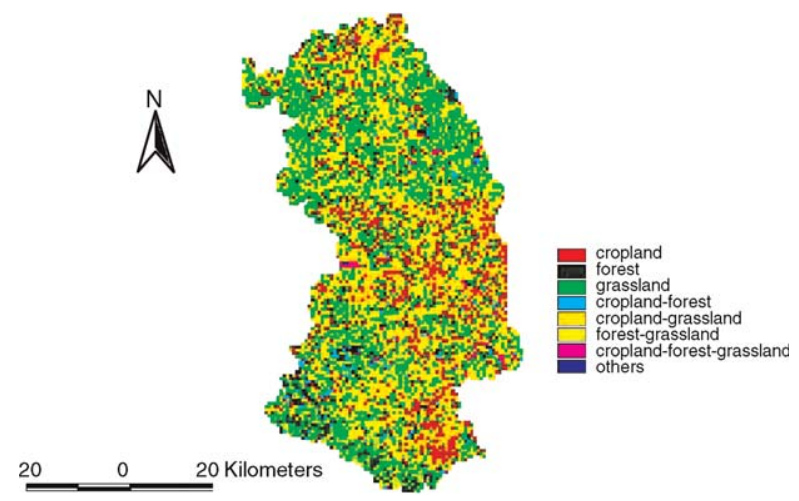

Fig. 2. The landscape map in 1980 in Ansai County.

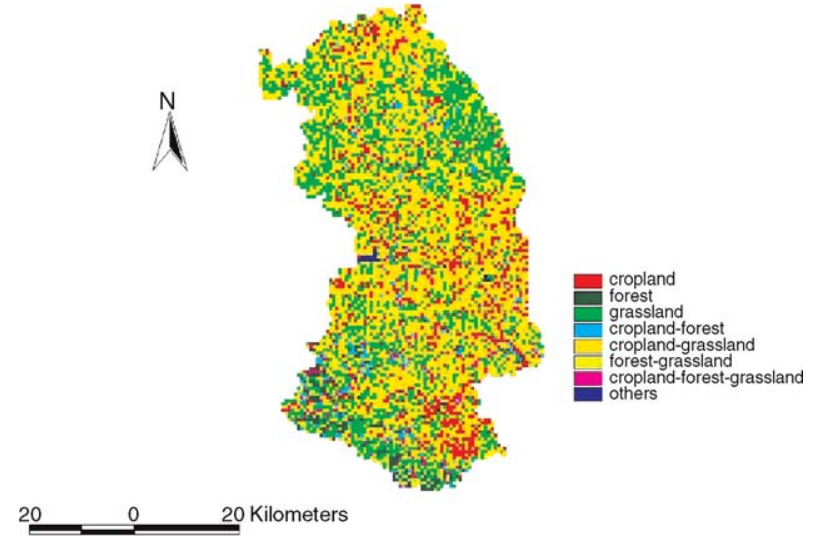

Fig. 3. The landscape map in 2000 in Ansai County.

Based on land use maps, eight landscape types were classified according to the dominating land use type (over $60 \%$ of landscape cell area) (Figs. 2 and 3). These dominating land use types include cropland (containing irrigated farmland, terrace farmland, sloping farmland and check-dam farmland), forest or woodland (including orchard land, dense woodland, sparse woodland and shrub land), grassland, mixed cropland-woodland, mixed cropland-grassland, mixed woodland-grassland, mixed cropland-woodland-grassland and other land use (including residential area, water body and unused land). To each landscape cell the dominant landscape type was assigned.

\subsection{Indicators}

A total of 14 variables describing landscape structure were derived from land use maps and used in the analysis according to the availability of data and a review of literature (Wrbka et al., 1998, 2004; Peterseil et al., 2004; Lausch and Herzog, 2002). These variables were used as predictors of the hemerobiotic state for each landscape cell and included: largest patch index (LPI), number of patches (NumP), mean patch size (MPS), patch size coefficient of variance (PSCoV), patch size standard deviation (PSSD), total edge (TE), edge density (ED), mean shape index (MSI), area weighted mean shape index (AWMSI), mean patch fractal dimension (MPFD), area weighted mean patch fractal dimension (AWMPFD), landscape shape index (LSI), Shannon's diversity index (SDI), and Shannon's evenness index (SEI). All variables were calculated for each of the $600 \mathrm{~m} \times 600 \mathrm{~m}$ of grid on landscape scale by using Arcview 3.2 and Patch grid model 3.1.

Because of the large hypsography in Loess hilly area, it appeared difficult to accurately aggregate landform indicators for the grid mesh of $600 \mathrm{~m} \times 600 \mathrm{~m}$ size. Therefore, landform indicators were not used in predicting hemerobiotic state of landscape cells.

\subsection{Statistical analyses}

A four-step procedure was then used in this study. At first, referring to an outline for the classification of land use 
intensity into hemerobic states (Zechmeister and Moster, 2001), the hemeroby value of each land use type was decided according to the relevant parameters based on the expert judgment and the experience of a small catchment field survey in Ansai County in 2004. Secondly, based on the hemeroby value of each land use type, the area weighted average value of the hemerobiotic states was computed for 154 random selected landscape sample cells for all eight landscape types. A similar method was recently adopted by Steinhardt et al. (1999) and Wrbka et al. (2004). Using the area weighted average value of hemerobiotic state of landscape cells $(n=154)$ as response, an ordinal logit regression model was constructed with the above mentioned 14 landscape variables as predictors by using SPSS (Version $10.0)$ at the $P<.05$ significance level. Thirdly, the resulting model was applied to the whole data set (8510 landscape cells of $600 \mathrm{~m} \times 600 \mathrm{~m}$ size in 1980 and 2000). The hemerobic states for each landscape cell in 1980 and 2000 were predicted by variables using the ordinal regression model. Lastly, we calculated the deviance of mean hemeroby situation within a respective landscape type and further the sustainability indicator of each landscape cell.

Mean values and standard deviation for each landscape type was calculated and compared to the predicted values of the landscape cells within these landscape types. The sustainability indicator value was calculated according to following the formula (Peterseil et al., 2004):

SUSI $=\frac{[\text { AvgHem_LandType }]-[\text { Hem_LandCell }]}{[\text { StdDevHem_LandType }]}$

where [AvgHem_LandType] is the mean predicted hemeroby value for a specific landscape type, [StdDevHem_LandType] is the standard deviation, and [Hem_LandCell] is the predicted hemeroby value of a landscape cell within the landscape type.

The resulting values were classified into five categories ranging from -2 to 2 . The value of -2 means a low sustainability and a very strong negative deviation of more than 1.5 standard deviations, and 2 means a high sustainability and a very strong positive deviation. The value 0 means that there is no or only a slight deviation from the average situation, with a moderate sustainability.

Table 1

Changes in land use between 1980 and 2000 in Ansai County (after Zhang, 2004)

\begin{tabular}{llc}
\hline Land use type & $1980(\%)$ & $2000(\%)$ \\
\hline Cropland & 37.28 & 31.87 \\
Woodland & 13.5 & 22.67 \\
Grassland & 36.29 & 42.23 \\
Residential area and transport & 1.27 & 1.77 \\
Water area & 3.73 & 1.15 \\
Unexploited area & 7.93 & .31 \\
\hline
\end{tabular}

Table 2

Proportions of different landscape cells between 1980 and 2000 in Ansai County

\begin{tabular}{lrc}
\hline Landscape type & $\begin{array}{l}1980 \\
\text { (cells \%) }\end{array}$ & $\begin{array}{l}2000 \\
\text { (cells \%) }\end{array}$ \\
\hline Cropland landscape & 13.5 & 10.7 \\
Woodland landscape & 2.2 & 2.1 \\
Grassland landscape & 32.2 & 32.6 \\
The mixed cropland-woodland landscape & 2.2 & 2.3 \\
The mixed cropland-grassland landscape & 44.8 & 47 \\
The mixed woodland-grassland landscape & 2.8 & 2.6 \\
The mixed cropland-woodland-grassland landscape & 2.1 & 2.4 \\
Others landscape & .1 & .3 \\
\hline
\end{tabular}

\section{Results}

\subsection{Changes of the landscape pattern between 1980 and 2000}

Large changes have occurred in landscape composition between 1980 and 2000 (Figs. 2 and 3). It indicates a consistency with the change of land use between 1980 and 2000 in Ansai County (Table 1). A large amount of sloping croplands was transformed into woodlands and grasslands. Hence, compared with 1980, there is a decrease in croplanddominated landscape and an increasing of in grasslanddominated landscape and the mixed landscape with cropland and grassland (Table 2). Cropland is the dominant land use type in this area. The proportion of cropland-dominated landscape cells and its percentage of the total area decreased from 13.5 to 10.7 and 37.28 to $31.87 \%$, respectively, during the period 1980-2000. Another significant land use type in the study area is grassland. Its percentage of the total area increased from 36.29 to $42.23 \%$ while its proportion of landscape cells increased a little from 32.2 to $32.6 \%$. Also the proportions of the mixed cropland-grassland landscape and the mixed cropland-grassland-woodland landscape increased from 44.8 to 47 and 2.1 to $2.4 \%$, respectively, during this period.

\subsection{Changes of the ecological sustainability of the agricultural landscape between 1980 and 2000}

It is assumed that present landscape structure mirrors historical processes that occurred in the landscape (Wrbka et al., 2004). The greater changes of the landscape pattern resulted in changes in the ecological sustainability of the agricultural landscape between 1980 and 2000 in Ansai County (Figs. 4 and 5). They indicate significant differences at both the whole landscape level and the class level during the period between 1980 and 2000. At the landscape level, the results show that the ecological sustainability of agricultural landscape tended to increase. On the one hand, the percentage of moderate to low sustainability landscape exhibited a little decrease, from 32 to $31 \%$. On the other hand, the proportion of moderate to high and high sustainability landscape increased from 30 to 34 and 2 to 


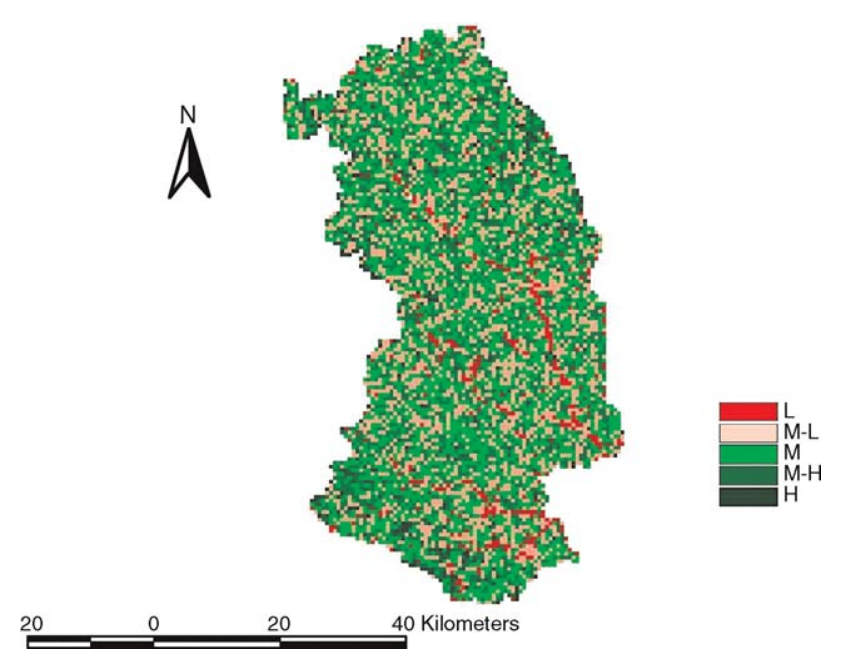

Fig. 4. The ecological sustainability of agricultural landscape in 1980 in Ansai County.

3\%, respectively, between 1980 and 2000 (Fig. 6). With respect to the class level, different landscape types that were dominated by different land use types showed various differences between both classes and different time steps by using $\chi^{2}$-test. The proportion of sustainability levels within the various landscape classes at the two time steps is shown in Figs. 7 and 8.

For farmland landscape where over $60 \%$ of landscape cell area dominated by farmland, the ecological sustainability status evolved in a more positive direction. Although the percentage of high sustainability landscapes decreased from 1.2 to $.5 \%$ between 1980 and 2000, the percentage of above moderate sustainability landscape increased from 74.6 to $85 \%$. At the same time, moderate to low sustainability and low sustainability landscapes decreased from 19 to 12.4 and 4.4 to $2.2 \%$, respectively, during this period.

With regard to forest and grassland landscapes, their ecological sustainability conditions suggested an effect of

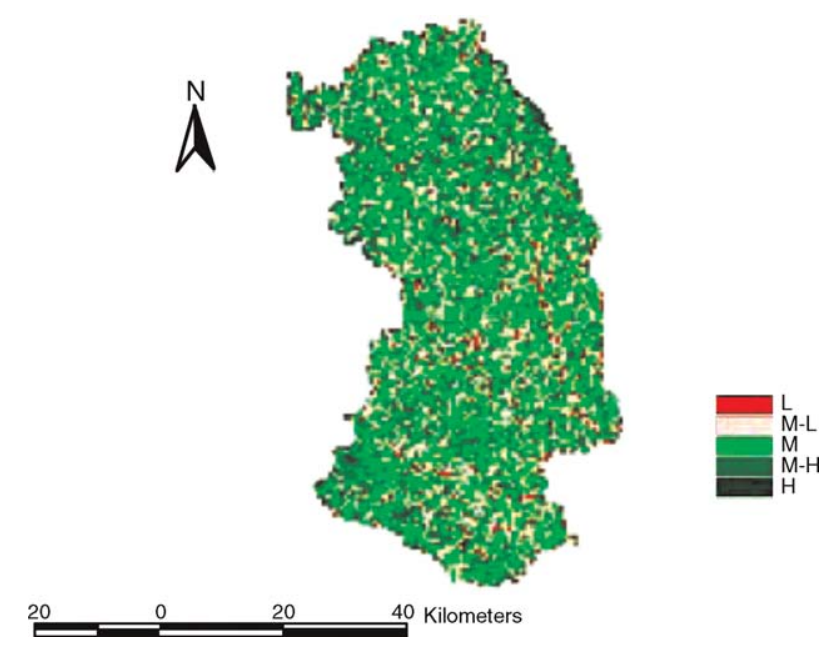

Fig. 5. The ecological sustainability of agricultural landscape in 2000 in Ansai County.

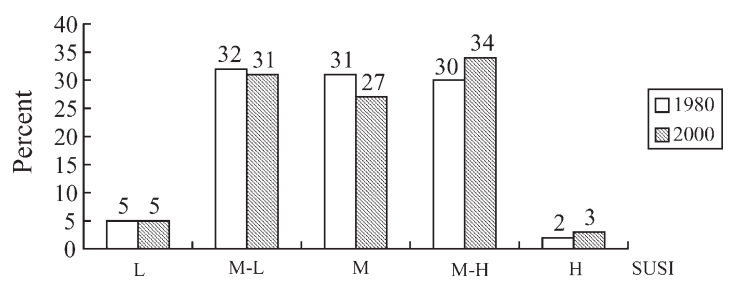

Fig. 6. Variances of ecological sustainability levels of agricultural landscape in Ansai County between 1980 and 2000 - L: low sustainability, ML: moderate to low sustainability, M: moderate sustainability, M-H: moderate to high sustainability, $\mathrm{H}$ : high sustainability.

polarization from a moderate level towards a more positive and more negative direction. However, in general, forest and grassland landscape still have a slightly negative trend. The percentage of above moderate sustainability landscapes decreased from 70 to 67 and 68.3 to $64.3 \%$, respectively.

As far as the mixed farmland-forest landscape is concerned, our results indicated few changes for its ecological sustainability pattern between 1980 and 2000 . In terms of the mixed farmland-grassland landscape and the mixed forest-grassland landscape, although their ecological sustainability conditions still suggested a polarization trend. In contrast to forest and grassland landscapes, as a whole these two mixed landscape types indicated a more positive deviation. The proportion of high sustainability landscapes and moderate to high sustainability landscapes obviously increased between 1980 and 2000. At the same time, the low sustainability landscapes decreased.

Regarding the mixed farmland-forest-grassland landscape which characterized by a mixture of three land cover types, the changes of ecological sustainability showed the decrease of low sustainability landscape and the increase of high sustainability landscape. The total proportion of high sustainability and moderate to high sustainability amounts to the highest proportion among the eight landscape types. So maybe it should be considered as one of the most sustainable landscape types in the study area.

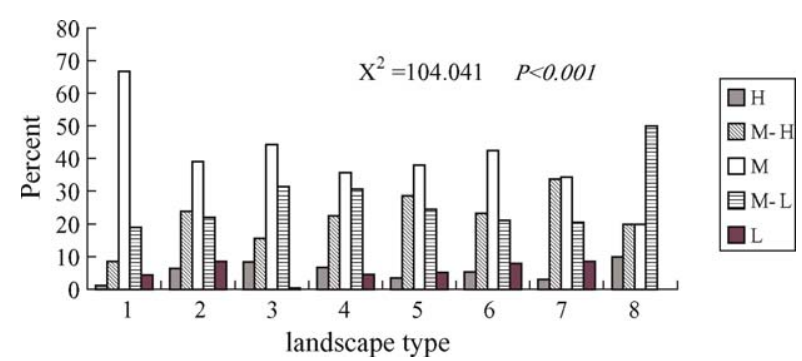

Fig. 7. Variances of ecological sustainability levels of different landscape types in 1980-1: cropland landscape, 2: woodland landscape, 3: grassland landscape, 4: the mixed cropland-woodland landscape, 5: the mixed cropland-grassland landscape, 6: the mixed woodland-grassland landscape, 7 : the mixed cropland-woodland-grassland landscape, 8: others landscape. 


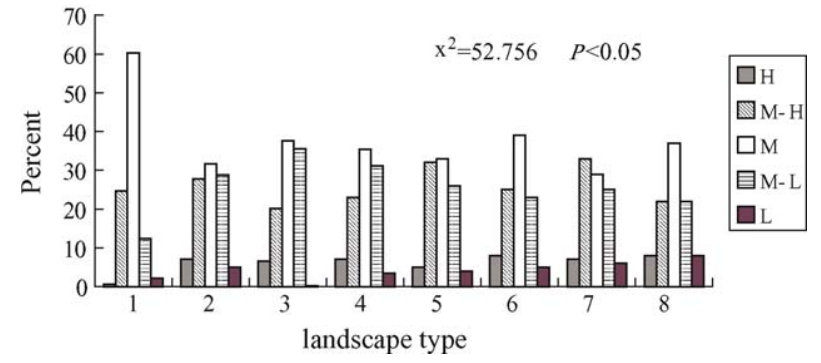

Fig. 8. Variances of ecological sustainability levels of different landscapes types in 2000 .

The eighth landscape type includes residential, water and bare areas and so on. This landscape type takes up less than $.3 \%$ of total landscape cells in 2000. Unlike the other landscapes where a polarization trend from moderate level towards a more positive and a more negative direction was noticed, there is an effect of the polarization from moderate to low sustainability level towards a lower and a moderate levels. The proportion of low sustainability landscape and moderate sustainability landscape increased, but the percentage of moderate to low sustainability landscape decreased obviously.

\subsection{Ordinal regression analysis between landscape metrics and the hemerobiotic states}

The ordinal regression model explained about $61 \%$ of the variance $\left(R^{2}=.61, P<.001\right)$ in the data. The results indicate that PSSD, TE, MSI, SEI and LSI are the significant predicators for the hemeroby of landscape cell (Table 3, $P<.05)$. The regression analysis results show a significant negative correlation between the hemerobiotic state and mean shape index (MSI) which describes the shape complexity of landscape elements. However, for the landscape pattern indicators, Shannon's evenness index (SEI) is found to be a significant factor positively correlated with the hemerobiotic state in this study.

\section{Discussion}

\subsection{The changes of agricultural landscape pattern and their driving forces}

The change of landscape structure greatly depends on the political, economic technological and demographic changes (Jelecek, 1984). As expected, with changes of the land use policy, the structural adjustment of the agricultural sector, the initiation of Chinese Family Planning and implementation of large-scale eco-environment conservation programmes, especially the execution of the integral soil erosion control project in 1981 and startup of Grain-for-Green Programme in 1999, dramatic changes have occurred in the land use structure and the composition of landscape pattern in Loess Plateau during the past two decades. Compared with 1980, there is a decrease in cropland-dominated landscape and an increase in grassland-dominated landscape and the mixed landscape with cropland and grassland in 2000.

As shown in relevant research conducted in a small catchment in Northern Loess Plateau, China (Zhang et al., 2004), the land use policy appeared to have a strong impact on the land use structure and the landscape pattern. At the end of 1978, the commune system was replaced by the household responsibility system, and the land was reallocated to individual farmers. To improve grain output, a part of pastures was reclaimed arable lands by farmers. So there are more landscapes dominated by cropland in 1980. Since 1992, the market-directed economic system replaced the planned economic system. At the same time, the structural of the agricultural sector was gradually adjusted from main crop planting to diversiform stock raising, economic crop planting and orchard, which resulted in a diversification of farmer income sources. A part of sloping farmland was replaced gradually by pasture and woodland. And with the development of rural economy, farming cannot compete with other means of bringing in income as a result of rigorous natural conditions, severe loss of soil and water and insufficient input. They may diminish agricultural

Table 3

Results of ordinal logit regression analysis for landscape structure indicators and the hemeroby

\begin{tabular}{|c|c|c|c|c|}
\hline Landscape structure indicators & Estimate & Wald & d.f. & Sig. \\
\hline NumP & -.845 & 1.494 & 1 & .222 \\
\hline MPS & .047 & .059 & 1 & .808 \\
\hline PSCoV & .034 & 1.382 & 1 & .240 \\
\hline PSSD & -.872 & 14.677 & 1 & .000 \\
\hline $\mathrm{TE}$ & -.031 & 31.201 & 1 & .000 \\
\hline ED & -.013 & .869 & 1 & .351 \\
\hline MSI & -12.047 & 4.214 & 1 & .040 \\
\hline AWMSI & 9.539 & 3.390 & 1 & .066 \\
\hline MPFD & 66.105 & 2.594 & 1 & .107 \\
\hline AWMPFD & -35.617 & .647 & 1 & .421 \\
\hline SDI & 1.772 & 2.025 & 1 & .155 \\
\hline SEI & 4.677 & 7.080 & 1 & .008 \\
\hline LPI & -.022 & .208 & 1 & 649 \\
\hline LSI & -72.916 & 30.551 & 1 & .000 \\
\hline
\end{tabular}

d.f.: degrees of freedom; Sig.: $P$-value. 
production and extensify land uses when more and more farmers become involved in non-farming activities, which may result in a part of sloping croplands being abandoned and becoming fallow or pasture. Consequently, the landscape pattern showed the gradual decrease of croplanddominated landscape and the greater increase of the mixed cropland-grassland landscape.

As one of the most important natural conservation project in the world, the Grain-for-Green Programme will inevitably promote the agricultural development and impact the land use. More and more sloping farmlands will be converted to woodlands and pastures. This policy would be the main driving force of landscape change and of improving the ecological sustainability of agricultural landscape in the Loess Plateau. However, the long-term sustainability of the Grain-for-Grain Programme is still in question. Further studies are still necessary on landscape sustainability monitoring in Loess Plateau in the future.

\subsection{The ecological sustainability of agricultural landscape change}

Similar to the some previous pertinent research works (e.g. Peterseil et al., 2004; Wrbka et al., 2004), this study also supports the 'pattern and process paradigm' (Odum and Turner, 1989). As demonstrated in this study, the changes in land use and land cover induced a variation of the landscape spatial pattern between different time steps, which further leads to the changes of the ecological sustainability of landscape both at landscape level and class level. At the whole landscape level, with the decrease of cropland and the increase of grassland and woodland, the ecological sustainability of agricultural landscape in Ansai County showed an improvement that the percentage of low sustainability landscape decreased and the proportion of high sustainability landscape increased from 1980 to 2000, although for some landscape types a negative tendency appeared. The most important reason was considered as the consequence that growing sloping croplands with higher hemeroby were being converted to woodlands and pastures with the lower land use intensity because of the changes of policy and the development of rural economy. Research implied further that the extension of sloping farmland, the acceleration of deforestation and cultivation of grassland, due to the increase in population and the concomitant requirement of grain, were the principal causes that accelerated soil erosion and nutrient loss in the Loess Plateau in the past decades (Shi and Shao, 2000; Fu, 1989). Sloping farmland is more susceptible than other land use types in the Loess Plateau (Fu et al., 2004). Therefore, conversion of sloping farmland to woodland and grassland is key to reducing soil erosion and enhancing sustainability of land use. For different landscape types, the mixed landscape cells that were dominated by a mixture of different land cover types tended towards higher sustainability. On the one hand, it is associated close with the calculation scale of landscape metrics and the method of landscape classification. This may allow us to understand the pattern-process relationships at landscape level and the magnitude and direction of landscape transformation processes. Considering the slightly negative trend of the woodland landscape and the grassland landscape, one plausible explanation for this situation could be that restored woodlands and pastures hold a low survival ratio in a short time due to Grain-forGreen Programme, which may impact the improvement of ecological sustainability of woodland and pasture landscapes. Further studies on relationship between landscape structure and ecological sustainability of landscape are essential to the sustainability of Grain-for-Green Programme and the sustainable development of rural area in the Loess Plateau.

\subsection{Landscape structure and the hemeroby}

The significant negative correlation between the hemerobiotic state and mean shape index (MSI) shows that the landscapes with low hemerobiotic state level and high ecological sustainability hold high patch shape complexity values. The similar phenomena were detected in northeastern Germany by Stachow and Piorr (1995) and in Austria by Wrbka et al. (1998). This indicates the growing human impact on the land may result in a landscape with decreasing geometrical complexity (Wrbka et al., 2004) and with decreasing the ecological sustainability. In addition, for the landscape pattern indicators, significant relationship to the hemerobiotic state could be shown. With the increasing intensity of human influence, the results indicate that the number of patches tends to decrease. The distribution of patches becomes more even and the ecological sustainability of landscapes decreases. Landscape cells characterized by the mixture of different land cover types are likely to have intermediate hemerobiotic static level and high ecological sustainability, such as the mixed farmland-forest-grassland landscapes which hold more proportion of high sustainability and moderate to high sustainability landscape cells than other landscape types. This may imply that the moderate disturb is favorable for ecological sustainability of landscapes.

It is shown that the concept of hemeroby, as a highly integrative indicator, provides a tool for the comparison of different landscapes. Variables describing the landscape structure turned out to be good predictors for land use intensity measured by the hemerobiotic state. Therefore, landscape structure seems to be a good predictor for land use intensity and ecological sustainability of landscape (Peterseil et al., 2004). In addition, many researches have revealed that changing grain size has a significant impact on landscape metrics and landscape metrics are sensitive to the calculation scale (O'Neill et al., 1996; Uuemaa et al., 2005). There will be various landscape metrics between finegrain and coarse-grain data due to aggregation effects. Hence, more research is needed to explore which grain scale 
is better for monitoring landscape pattern and which kind of landscape classification can bring optimal result in the Loess Plateau in China.

\subsection{Data limitation}

The landform is one of the important natural factors that affect human activities and land use change. Especially in Loess hilly area (Fu et al., 2006), the elevation varies much greater than the other areas. So slope becomes an important indicator for studies that deal with ecological process in Loess Plateau, such as the loss of soil and water and land use change. However, taking into account the bigger height difference in a small area in Loess hilly area, the landform indicators were not included into predicators for the hemeroby of landscape, which would be a shortcoming of this study and also a challenge in the future. As Wrbka et al. (2004) and Peterseil et al. (2004) noted that the coarse spatial resolution of Landsat TM5 images of $30 \mathrm{~m} \times 30 \mathrm{~m}$ may cause problems when depicting fine-grained agricultural landscapes. We realize that it could be insignificant to select smaller spatial reference units than $600 \mathrm{~m} \times 600 \mathrm{~m}$ size because of relative monotonous land use and cover in Loess hilly area while it is a difficulty to derive accurately landform indicators values for bigger than $600 \mathrm{~m} \times 600 \mathrm{~m}$ size of landscape cells in Loess hilly area due to higher difference of elevation in a small area. Despite these problems, satellite images are one major data source for landscape assessment on a regional scale. The encountered constraints can be considered as a more technical problem. Methodological enhancement is needed to solve the shortcomings of data. With comprehensive application of high-resolution remote sensing data in the future, it is impossible for assessment of environmental indicators. Besides the use of high-resolution satellite images, a large number of sample plots for the field survey may help to solve this problem (Peterseil et al., 2004).

\section{Conclusions}

The analysis of the evaluation of the ecological sustainability of agricultural landscape in Ansai County, China between 1980 and 2000 showed that major changes have occurred in landscape pattern and in the ecological sustainability of the landscapes during the past two decades. These changes were driven by changes of the land use policy, the structural adjustment of the agricultural sector, the initiation of Chinese Family Planning Policy and implementation of large-scale eco-environment conservation programmes, e.g., the Grain-for-Green Programme. The proportion of cropland-dominated landscape decreased sharply and the percentage of grassland-dominated landscape, the mixed farmland-grassland landscape and the mixed farmland-forest-grassland landscape increased between 1980 and 2000. Although the sustainability of some landscape types appeared a negative tendency, as a whole the ecological sustainability of agricultural landscape tended to increase. From an ecological viewpoint, the present landscape structure and pattern is more sustainable than the former, the Grain-for-Green Programme is essential to control soil erosion and sustainable development of the Loess Plateau in China.

As a crucial natural factor that influencing human activities and ecological process in Loess Plateau, landform indicators are essential for judgment the intensity of soil erosion and the sustainability of land use. Due to limited data and technical problems, the landform indicators are not integrated into this study. Thereby, more attention should be paid to this aspect in future studies in order to better understand the hemeroby of landscape in Loess Plateau.

As a highly integrative indicator, the concept of hemeroby provides an approach for the comparison of different land use pattern. Further studies on the relationship between landscape structure and the hemeroby of landscape need to be done in order to better understand the landscape sustainability and the ways to protect the biodiversity at different spatial and temporal scales.

In addition, the SINUS approach appears to be an accessible tool for assessing changes of landscape pattern and certain ecological process between different time steps using information about the landscape structure and landscape composition as shown in this study. As noted by Peterseil et al. (2004), with such a framework it should be possible to verify whether certain activities or policies are really supporting sustainable development of region or not. Ideally, a holistic appraisal of sustainability should integrate environmental, economic and social dimensions (Allen et al., 1991). Although this study does not include social and economic indicators, it can provide a good framework to incorporate additional indicators when they become available.

\section{Acknowledgments}

This article was supported by the National Natural Science Foundation of China (40321101) and was partially funded by the bilateral Flanders-China project (BIL0209). We would like to thank editor and the referees of this paper for their useful comments and suggestions.

\section{References}

Allen, P., Van-Dusen, D., Lundy, J., Gliessman, S., 1991. Integrating social, environmental and economic issues in sustainable agriculture. Am. J. Altern. Agric. 6 (1), 34-39.

Bureau of Resource, Environmental Science and Technology, Chinese Academy of Sciences (BREST-CAS), 1992. Development and Comprehensive Treatment on Small Catchment in Loess Plateau. China Science and Technology Literature Press, Beijing (in Chinese). 
Chen, L.D., Wang, J., Fu, B.J., Qiu, Y., 2001. Land use change in a small catchment of northern Loess Plateau, China. Agric. Ecosyst. Environ. 86, 163-172.

FAO-Unesco, Y., 1974. Soil Map of the World (1:5000000) Food and Agricultural Organisation of the United Nations. Unesco, Paris.

Forman, R.T., 1995. Land Mosaics-The Ecology of Landscapes and Regions. Cambridge University Press, Cambridge, MA.

Forman, R.T., Gordron, M., 1986. Landscape Ecology. Wiley, New York, p. 620 .

Fu, B., Gulinck, H., 1994. Land evaluation in an area of severe erosion: the Loess Plateau of China. Land Degrad. Rehabil. 5, 33-40.

Fu, B.J., 1989. Soil erosion and its control in the Loess Plateau of China. Soil Use Manage. 5, 76-82.

Fu, B.J., Chen, L.D., 2000. Agricultural landscape spatial pattern analysis in the semi-arid area of the Loess Plateau, China. J. Arid Environ. 44, 291303.

Fu, B.J., Meng, Q.H., Qiu, Y., Zhao, W.W., Zhang, Q.J., Davidson, D.A., 2004. Effects of land use on soil erosion and nitrogen loss in the hilly area of the Loess Plateau, China. Land Degrad. Dev. 15, 87-96.

Fu, B.J., Zhang, Q.J., Chen, L.D., Zhao, W.W., Gulinck, H., Liu, G.B., Yang, Q.K., Zhu, Y.G., 2006. Temporal change in land use and its relationship to slope degree and soil type in a small catchment on the Loess Plateau of China. Catena 65 (1), 41-48.

Goudie, A., Viles, H., 1997. The Earth Transformed-An Introduction to Human Impacts on the Environment. Blackwell, Oxford.

Jalas, J., 1955. Hemerobe and hemechore Pflanzenarten. Ein terminologischer Reformversuch. Acta Fauna Flora Femm. 72 (11), 1-15.

Jelecek, L., 1984. Main historical changes in spatial organization of agriculture in Bohemia in the 2nd half of the 19th century. Hist. Geogr. 23, 171-218.

Kim, Y.M., Zerb, S., Kowarik, I., 2002. Human impact on flora and habits in Korean rural settlements. Preslia, Praha 74, 409-419.

Krausmann, F., Haberl, H., Schulz, N.B., Erb, K.H., Darge, E., Gaube, V., 2003. Land-use change and socio-economic metabolism in Austria. Part I. Driving forces of land-use change: 1950-1995. Land Use Policy 20, $1-20$.

Krummel, J.R., Gardner, R.H., Sugihara, G., O'Neill, R.V., Coleman, P.R., 1987. Landscape pattern in a disturbed environment. Environ. Oikos 48, 321-324.

Lausch, A., Herzog, F., 2002. Applicability of landscape metrics for the monitoring of landscape change: issues of scale, resolution and interpretability. Ecol. Indicators 2, 3-15.

Lu, C.H., van Ittersum, M.K., Rabbinge, R., 2004. A scenario exploration of strategic land use options for the Loess Plateau in northern China. Agric. Syst. 79, 145-170.

Moser, D., Zechmeister, H.G., Plutzar, C., Sauberer, N., Wrbka, T., Grabherr, G., 2002. Landscape shape complexity as an effective measure for plant species richness in rural landscapes. Landscape Ecol. 17 (7), 657669.

Odum, E.P., Turner, M.G., 1989. Georgia landscape: a changing resource. In: Zonneveld, I.S., Forman, R.T. (Eds.), Changing Landscapes: An Ecological Perspective. Springer, New York, pp. 137-146.

O’Neill, R.V., Hunsaker, C.T., Timmins, S.P., Jackson, B.L., Jones, K.B., Riitters, K.H., Wickham, J.D., 1996. Scale problems in reporting landscape pattern at the regional scale. Landscape Ecol. 11, 169-180.

Peterseil, J., Wrbka, T., Plutzar, C., Schmitzberger, I., Kiss, A., Szerencsits, E., Reiter, K., Schneider, W., Suppan, F., Beissmann, H., 2004. Evaluating the ecological sustainability of Austrian agricultural landscapes-the SINUS approach. Land Use Policy 21, 307-320.

Rex, K.D., Malanson, G.P., 1990. The fractal shape of riparian forest patches. Landscape Ecol. 4 (4), 249-258.

Shi, H., Shao, M.A., 2000. Soil and water loss from the Loess Plateau in China. J. Arid Environ. 45, 9-20.
Stachow, U., Piorr, H.P., 1995. Gesamtbewertung der Ergebnisse der Studie Synthese zur Naturraum- und Biotopausstattung. In: Bork, H.R., Dalchow, C., Kachele, H., Piorr, H.P., Wenkel, K.O. (Eds.), Agrarlandschaftswandel in Nordost-Deutschland unter veranderten Rahmenbedingungen—okologische und okonomische Konsequenzen. Ernst and Sohn Verlag, Berlin, pp. 341-346.

Steinhardt, U., Herzog, F., Lausch, A., Muller, E., Lehmann, S., 1999. Hemeroby index for landscape monitoring and evaluation. In: Pykh, Y.A., Hyatt, D.E., Lenz, R.J. (Eds.), Environmental Indices-System Analysis Approach. EOLSS Publishers, Oxford, pp. 237-254.

Sukopp, H., 1976. Dynamik und Konstanz in der Flora der Bundesrepublik Deutschland. Schr.-R. f. Vegetationskunde 9-27.

Turner, M.G., 1990. Spatial and temporal analysis of landscape patterns. Landscape Ecol. 4 (1), 21-30.

Turner, M.G., Ruscher, C.L., 1988. Changes in the spatial patterns of land use in Georgia. Landscape Ecol. 1 (4), 241-251.

Turner II, B.L., Moss, R.H., Skole, D.L., 1993. Relating land use and global land-cover change: a proposal for on IGBP-HDP Core Product. IGBP Report 24, Stockholm, Sweden, HDP Report 5.

Turner, B.L., Clark, W.C., Kates, R.W., Richards, J.F., Mathews, J.T., Meyer, W.B., 1990. The Earth as Transformed by Human Action: Global and Regional Changes in the Biosphere over the Past 300 Years. Cambridge University Press, Cambridge.

Uuemaa, E., Roosaare, J., Mander, U., 2005. Scale dependence of landscape metrics and their indicatory value for nutrient and organic matter losses from catchments. Ecol. Indicators 5, 350-369.

Verburg, P.H., Chen, Y.Q., 2000. Multiscale characterization of land-use pattern in China. Ecosystem 3, 369-385.

Vitousek, P.M., 1992. Global environmental change: an introduction. Annu. Rev. Ecol. Syst. 23, 1-14.

Vitousek, P.M., Mooney, H.A., Lubchenko, J., Melillo, J.M., 1997. Human domination of earth's ecosystems. Science 277, 494-499.

Wang, F., Li, R., Wen, Z.M., Zhou, M.L., 2003. Problems and proposals on policy of converting cropland into forest and grassland: a case-based study. J. Northwest Sci-Tech. Univ. Agric. Forest. (Social Science Edition) 3, 60-65 (in Chinese).

World Wildlife Fund, 2004. Report suggests China's ‘Grain-to-Green’ plan is fundamental to managing water and soil erosion [Internet] 2003 [cited January 8, 2004]. Available from http://www.wwfchina.org/english/ local.php?loca $=159$.

Wrbka, T., Reiter, K., Szerencsits, E., Beismann, H., Mandl, P., Bartel, A., Schneider, W., Suppan, F., 1998. Landscape structure derived from satellite images as indicator for sustainable landuse. In: Nieuwenhuis G, J.A., Vaughan, R.A., Molenaar, M. (Eds.), Operational Remote Sensing for Sustainable Development, Proceedings of the 18th EARSeL Symposium Enschede, Balkema, Rotterdam, pp. 119127.

Wrbka, T., Erb, K.H., Schulz, N.B., Peterseil, J., Hahn, C., Haberl, H., 2004 Linking pattern and process in cultural landscapes. An empirical study based on spatially explicit indicators. Land Use Policy 21, 289306.

Zechmeister, H.G., Moster, D., 2001. The influence of agricultural land-use intensity on bryophyte species richness. Biodivers. Conserv. 10, 16091625.

Zhang, Q.J., Fu, B.J., Chen, L.D., Zhao, W.W., Yang, Q.K., Liu, G.B., Gulinck, H., 2004. Dynamics and driving factors of agricultural landscape in the semiarid hilly area of the Loess Plateau, China. Agric. Ecosyst. Environ. 103, 535-543.

Zhang, Q.J., 2004. Multi-scale characteristics of land use change and its driving forces in the Loess Plateau semi-arid hilly area. PhD Thesis. Chinese Academy of Sciences.

Zhang, Z.X., 2002. Land use maps in Ansai County in 1980 and 2000, the institute of remote sensing applications. Chinese Acad. Sci.. 